\title{
Pengaruh Kualitas Komite Audit dan Ukuran Kantor Akuntan Publik terhadap Manajemen Laba
}

\author{
(Studi Pada Perusahaan Manufaktur Sektor Industri Dasar dan Kimia \\ yang Terdaftar di BEl periode 2015-2017) \\ Nazila Alfiyasahra \\ Auliffi Ermian Challen \\ Program Studi Akuntansi Fakultas Ekonomi Dan Bisnis Universitas YARSI \\ auliffi.ermian@yarsi.ac.id
}

\begin{abstract}
This research aims to determine the effect of the quality of the audit committee and the size of the public accounting firm on earnings management. The audit committee uses the proxy size, the number of meetings, independent member, and the expertise of audit committee. This research uses secondary data, namely the company in the category of manufacturing sector of basic industry and chemical listed on the Indonesia Stock Exchange (IDX). The sample used as many as 16 companies with the period 2015-2017 through a purposive sampling method. The analytical method used is multiple regression. Based on the results of the research concluded that the independent audit committee has a positive effect on earnings management, but the audit committee size, the number of audit committee meetings, the expertise of the audit committee, and the size of the public accounting firm have no influence on earnings management.
\end{abstract}

Keywords: $\quad$ audit committee quality, public accounting firm size, earnings management

\section{ABSTRAK}

Penelitian ini bertujuan untuk mengetahui pengaruh kualitas komite audit dan ukuran kantor akuntan publik terhadap manajemen laba. Komite audit menggunakan proksi berupa jumlah rapat, anggota independen, dan keahlian komite audit. Penelitian ini menggunakan data sekunder, yaitu perusahaan yang masuk dalam kategori sektor manufaktur industri dasar dan kimia yang terdaftar di Bursa Efek Indonesia (BEI). Sampel yang digunakan sebanyak 16 perusahaan dengan periode 2015-2017 yang diperoleh melalui metode purposive sampling. Metode analisis yang digunakan adalah regresi berganda. Berdasarkan hasil penelitian disimpulkan bahwa komite audit independen mempunyai pengaruh positif terhadap manajemen laba, tetapi ukuran komite audit, jumlah rapat komite audit, keahlian komite audit, dan ukuran kantor akuntan publik tidak berpengaruh pada manajemen laba.

Kata kunci: kualitas komite audit, ukuran kantor akuntan publik, manajemen laba 


\section{PENDAHULUAN}

Skandal pelaporan akuntansi sudah menjadi tema yang menarik diperbincangkan karena mengenai trik penyampaian informasi keuangan, salah satunya adalah tindakan manajemen laba. Penyusun laporan keuangan akan merasa benar, tetapi pengguna laporan keuangan akan menyalahkan hal tersebut karena tidak sesuai dengan peraturan. Akibatnya adalah selalu terjadi kecurangan perusahaan yang menggunakan informasi keuangan sebagai media (Yateno 2016). Kasus ini membuat keterlibatan beberapa pihak, diantaranya yaitu keterlibatan organ perusahaan seperti komisaris, komite audit, audit internal hingga audit eksternal dan para kepentingan perusahaan lainnya. Beberapa penelitian seperti Kusumaningtyas dan Farida (2015), Mughni dan Cahyonowati (2015), Nugraha (2016), Marsha dan Gozali (2017), Sihombing dan Laksito ( 2017), Satrio et.al, (2018) yang menunjukkan bahwa kegiatan manajemen laba dilatarbelakangi oleh beberapa faktor dari internal perusahaan.

Manajemen laba sebagai tindakan yang dilakukan oleh manajer untuk menurunkan atau menaikkan laba pada perusahaan yang dikelola baik legal maupun illegal (Lufita dan Suryani 2018). Dinyatakan legal, apabila cara dalam merubah angka tidak menyalahi aturan pelaporan keuangan dalam Standar Akuntansi Keuangan (SAK). Sedangkan dinyatakan illegal apabila pelaporan transaksi pendapatannya dilakukan secara fiktif, yakni dengan menambah (mark-up) atau mengurangi (mark-down) nilai dari transaksi atau tidak melaporkan sejumlah transaksi sehingga dicapai laba yang dikehendaki (Purnomo dan Pratiwi, 2009).

Watts dan Zimmerman (1986) dalam Suri dan Dewi (2018) mengungkapkan bahwa faktor yang dilakukan perilaku manajer pemilihan kebijakan akuntansi adalah hipotesis rencana bonus (bonus plan hypothesis), hipotesis ekuitas utang (debt covenant hypothesis), hipotesis biaya politis (political cost hypothesis), motivasi pajak (tax motivation), pergantian CEO dan Initial Public Offering. Tindakan manajemen laba telah mengurangi kepercayaan investor dalam kualitas pelaporan keuangan. Oleh karena itu, harus ada metode pengendalian untuk menyesuaikan perbedaan kepentingan antara manajemen dengan pemegang saham yaitu good corporate governance (Dewi dan Khoiruddin, 2016). Menurut Chen et al. (2007), peran aktor tata kelola perusahaan seperti komite audit dan auditor eksternal sangat dibutuhkan untuk memberikan fungsi pengawasan di dalam dan di luar perusahaan sehingga nantinya akan melingkup serta menahan perilaku manajemen untuk melakukan manajemen laba.

Good Corporate Governance berfungsi untuk mengurangi masalah pada tata kelola perusahaan dan membentuk pola kerja manajemen yang terbuka, efektif dan efisien. Seorang investor akan menginvestasikan dananya ke perusahaan jika tata kelola perusahaan dapat menciptakan hasil kinerja perusahaan yang bagus serta meningkatkan kualitas informasi laporan keuangan perusahaan (Khurnanto dan Syaffrudin 2015). Jika tata kelola perusahaan ingin berjalan dengan baik dan tepat di perusahaan, maka diperlukan adanya suatu sistem pengawasan yang dilakukan oleh dewan komisaris. Dalam melaksanakan tugas dan fungsi pengawasannya, dewan komisaris menghabiskan waktu yang efisien dan memanfaatkan keahlian individu masing-masing direkturnya melalui komite-komite perusahaan (Kusumaningtyas dan Farida 2015).

Komite audit yang melakukan fungsi pengawasan pelaporan keuangan perusahaan merupakan salah satu faktor penting dalam tata kelola perusahaan. Selain peran penting pada komite audit selaku organ 
internal perusahaan, peran kantor akuntan publik selaku pihak luar/eskternal juga menjadi faktor dalam mempengaruhi kualitas pelaporan keuangan.

Menurut Halim (2008), komite audit bertindak sebagai penghubung antara manajemen dan auditor. Keberadaan komite audit harus mampu memberikan pengawasan terhadap manajamen sehubungan dengan pengendalian internal perusahaan dan pelaporan keuangannya. Komite audit sebagai organ internal perusahaan harus dapat memenuhi tugas untuk melakukan pengawasan terhadap kredibilitas laporan keuangan, maka diperlukan juga auditor eksternal untuk melaksanakan fungsi pengawasan dari pihak eksternal. Oleh karena itu, penetapan Kantor Akuntan Publik Big four diduga dapat mengurangi manajemen laba serta dapat meningkatkan kredibilitas dari laporan keuangan (Rahmadani dan Haryanto, 2018). Komite audit dan kantor akuntan publik perlu melakukan pengendalian yang baik sehingga dapat mengurangi adanya dorongan dari manajemen untuk memanipulasi laba (Zgarni et al. 2016).

Berdasarkan uraian dan penjelasan latar belakang diatas, maka penelitian ini akan menguji tentang pengaruh kualitas komite audit dan ukuran kantor akuntan publik terhadap manajemen laba yang dilakukan pada perusahaan manufaktur sektor industri dasar dan kimia yang terdaftar di Bursa Efek Indonesia periode tahun 2015-2017. Dalam penelitian ini, komite audit menggunakan beberapa proksi, diantaranya yaitu ukuran komite audit, jumlah pertemuan komite audit, komite audit independen dan keahlian komite audit.

\section{TELAAH LITERATUR DAN PENGEMBANGAN HIPOTESIS}

\section{Teori Agensi (Agency Theory)}

Perspektif teori keagenan merupakan teori yang digunakan dalam memahami isu manajemen laba. Jensen dan Mckeling (1976) mengungkap dasar teori keagenan atas dasar berbagai dimensi dan keterlibatan hubungan kagenan. Hubungan keagenan adalah dimana hubungan antara prinsipal dan agen yang mana prinsipal memerintahkan agen untuk melakukan dan memberi kewenangan agar membuat keputusan yang baik.

\section{Auditing}

Pengertian auditing adalah suatu pengumpulan dan proses evaluasi atas bukti informasi dalam rangka menentukan dan pelaporan derajat kesesuaian antara informasi tersebut dengan kriteria yang telah ditetapkan. Auditor yang kompeten dan independen sangat diperlukan dalam melakukan proses audit. Tujuan audit adalah agar auditor memberikan suatu pendapat pada laporan keuangan, apakah penyajiannya dilakukan secara wajar dan sesuai dengan standar akuntansi keuangan yang berlaku (Arens et al, 2014, 2).

\section{Good Corporate Governance}

Pedoman Good Corporate Governance menyatakan bahwa dewan komisaris wajib membentuk komite audit yang beranggotakan 1 (satu) atau lebih anggota dewan komisaris. Dewan komisaris dapat meminta pihak luar dengan berbagai keahlian, pendidikan, kualitas dan pengalaman lain yang dibutuhkan untuk diposisikan sebagai anggota komite audit (Prabowo, 2018, 47). 


\section{Komite Audit}

Menurut Peraturan Otoritas Jasa Keuangan tentang Pembentukan dan Pedoman Pelaksanaan Kerja Komite Audit, menyatakan bahwa Komite Audit harus beranggotakan paling sedikit 3 (tiga) orang anggota serta salah satu anggota berasal dari Komisaris Independen atau pihak luar yang merangkap sebagai ketua komite audit, lalu memiliki minimal 1 (satu) anggota yang memiliki spesialisasi di bidang akuntansi maupun keuangan, wajib mengadakan rapat rutin paling sedikit 1 (satu) kali dalam 3 (tiga) bulan dan bertindak secara independen dalam melaksanakan tugas, fungsi dan tanggung jawabnya (OJK 2015). Berdasarkan tugas dan fungsi dari komite audit yang utama dalam melakukan fungsi pegawasan, pada penelitian ini kualitas komite audit diproksikan ke dalam beberapa hal yang terkait, yaitu ukuran komite audit, jumlah pertemuan komite audit, komite audit independen, dan keahlian komite audit.

\section{Ukuran Kantor Akuntan Publik}

De Angelo (1981) mengungkapkan bahwa kualitas audit yang dilakukan oleh auditor eksternal dapat dilihat dari besar atau kecilnya kantor akuntan publik. Kantor Akuntan Publik Bigfour dipersepsikan mampu melakukan audit yang lebih berkualitas dibandingkan dengan Kantor Akuntan Publik Non-Bigfour. Hal tersebut karena kantor akuntan publik Bigfour memiliki banyak sumber daya, klien dan reputasi yang telah dianggap baik oleh masyarakat, sehingga mereka dapat melakukan auditnya dengan lebih baik (Christiani dan Nugrahanti 2014).

\section{Manajemen Laba}

Menurut Scott $(2012,325)$ manajemen laba merupakan pemilihan keputusan kebijakan akuntansi tertentu oleh manajer yang dianggap dapat mencapai tujuan yang diinginkan, seperti meninggikan nilai laba atau mengurangi kerugian yang dilaporkan. Menyampaikan informasi yang berguna bagi pihak-pihak yang berkepentingan merupakan kewajiban tiap perusahaan. Salah satu informasi yang sangat pening untuk pengambilan keputusan adalah informasi laba perusahaan. Informasi laba perusahaan menjadi hal yang utama untuk melihat kinerja dan pertanggungjawaban manajemen perusahaan.

\section{Pengembangan Hipotesis}

\section{Pengaruh Ukuran Komite Audit Terhadap Manajemen Laba}

Ukuran komite audit menunjukkan jumlah anggota komite audit yang dimiliki sebuah perusahaan. Dalam Peraturan OJK Nomor 55 Tahun 2015 pasal 4 disebutkan komite audit paling sedikit terdiri dari 3 (tiga) orang anggota yang berasal dari Komisaris Independen dan Pihak dari luar Emiten atau Perusahaan Publik. Semakin banyak jumlah anggota atau ukuran komite audit yang dimiliki oleh sebuah perusahaan dapat menunjukkan kinerja sebuah perusahaan semakin baik karena adanya pengawasan yang dilakukan oleh anggota komite audit. Hal ini tentunya dapat menurunkan manajemen laba yang dilakukan oleh manajemen perusahaan. Hal ini didukung dengan penelitian dari Sihombing dan Laksito (2017), Marsha dan Ghozali (2017), dan Sari (2017), yang menyatakan bahwa terdapat hubungan negatif antara ukuran komite audit dengan manajemen 
laba. Sehingga dapat dikatakan bahwa semakin besar ukuran komite audit dapat meminimalisasi terjadinya manajemen laba. Berdasarkan uraian dan penjelasan di atas, maka hipotesis yang akan diuji adalah sebagai berikut:

H1: Ukuran Komite Audit berpengaruh terhadap Manajemen Laba

\section{Pengaruh Jumlah Pertemuan Komite Audit Terhadap Manajemen Laba}

Jumlah pertemuan rapat komite audit menunjukkan dalam setahun berapa kali komite audit mengadakan pertemuan. Dalam Peraturan OJK Nomor 55 Tahun 2015 pasal 13 disebutkan komite audit mengadakan rapat secara berkala paling sedikit 1 (satu) kali dalam 3 (tiga) bulan. Apabila semakin sering komite audit mengadakan rapat maka akan semakin intens untuk melakukan pembahasan kegiatan perusahaan dan laporan keuangan, sehingga dapat berdampak pada menurunnya manajemen laba yang dilakukan perusahaan. Hal ini sejalan dengan penelitian Sihombing dan Laksito (2017), Marsha dan Ghozali (2017) yang membuktikan bahwa jumlah pertemuan komite audit berpengaruh negatif terhadap manajemen laba. Sehingga dapat dikatakan bahwa semakin sering pertemuan komite audit dapat meminimalisasi terjadinya manajemen laba. Berdasarkan uraian dan penjelasan diatas, maka hipotesis yang akan diuji adalah sebagai berikut:

H2: Jumlah Pertemuan Komite Audit berpengaruh terhadap Manajemen Laba

\section{Pengaruh Komite Audit Independen Terhadap Manajamen Laba}

Karakteristik komite audit yang dapat meningkatkan fungsi pengawasan, salah satunya adalah independensi. Anggota komite audit independen adalah anggota dari pihak independen yang tidak memiliki hubungan langsung kepada pihak perusahaan. Semakin banyaknya anggota komite audit yang independen diharapkan akan mengurangi manajemen laba sehingga perusahaan dapat menghasilkan kualitas laporan keuangan yang semakin baik. Hal ini sejalan dengan Kankanamge (2016) mengungkapkan bahwa komite audit independen berpengaruh negatif terhadap manajemen laba. Berdasarkan uraian dan penjelasan diatas, maka hipotesis yang akan diuji adalah sebagai berikut:

H3: Komite Audit Independen berpengaruh terhadap Manajemen Laba

\section{Pengaruh Keahlian Komite Audit Terhadap Manajemen Laba}

Komite Audit adalah komite yang dibentuk oleh dan bertanggung jawab kepada Dewan Komisaris dalam membantu melaksanakan tugas dan fungsi Dewan Komisaris sebagai pengawas. Dalam Peraturan OJK Nomor 55 Tahun 2015 pasal 7e disebutkan bahwa komite audit wajib mempunyai paling sedikit 1 (satu) anggota dengan berlatar belakang pendidikan dan keahlian di bidang akuntansi dan keuangan. Hal ini sejalan dengan penelitian Ayemere dan Elijah (2015) dan Mughni dan Cahyonowati (2015) menyatakan bahwa keahlian komite audit berpengaruh negatif terhadap manajemen laba. Berdasarkan uraian dan penjelasan diatas, maka hipotesis yang akan diuji adalah sebagai berikut:

H4: Keahlian Komite Audit berpengaruh terhadap Manajemen Laba 


\section{Pengaruh Ukuran Kantor Akuntan Publik Terhadap Manajemen Laba}

Di Indonesia, ukuran KAP dapat dibedakan 2 macam yaitu: KAP big four dan KAP non big four. KAP big four diketahui memiliki sumber daya dan pengalaman yang lebih baik untuk memberikan kualitas audit yang berkualitas dibandingkan dengan KAP non big four. Apabila perusahaan diaudit oleh KAP Big four berarti menunjukkan kinerja semakin baik sehingga akan semakin menurunkan indikasi terjadinya manajemen laba (Sari, 2017). Hal ini sejalan dengan penelitian Idris et al. (2018) yang menunjukkan bahwa ukuran Kantor Akuntan Publik berpengaruh negatif terhadap manajemen laba. Berdasarkan uraian dan penjelasan diatas, maka hipotesis yang akan diuji adalah sebagai berikut:

H5: Ukuran Kantor Akuntan Publik berpengaruh terhadap Manajemen Laba

\section{METODE PENELITIAN}

\section{Variabel Independen}

Variabel independen merupakan variabel yang menjadi sebab perubahaannya atau yang mempengaruhi atas munculnya variabel dependen (Sugiyono, 2017). Variabel independen penelitian ini adalah faktor yang diduga mempengaruhi manajemen laba yakni ukuran komite audit, jumlah pertemuan komite audit, komite audit independen, keahlian komite audit dan ukuran kantor akuntan publik.

\section{Variabel Dependen}

Variabel dependen merupakan variabel yang menjadi akibat atau keberadaannya dipengaruhi oleh timbulnya variabel independent (Sugiyono 2017). Variabel dependen penelitian ini adalah manajemen laba yang diukur menggunakan Discretionary Accruals. Pengukuran discreationary accruals menggunakan Model Jones (1991) yang dimodifikasi oleh Deschow et al. (1995). Model ini berfokus pada total akrual sebagai sumber informasi manipulasi akuntansi atau manajemen laba. Secara spesifik, model ini membagi total akrual menjadi akrual diskresioner dan akrual non-diskresioner. Akrual diskresionerlah yang digunakan sebagai estimasi manipulasi akuntansi.

\section{Metode Analisis}

Metode analisis data dalam penelitian ini adalah dengan menggunakan teknik analisis kuantitatif. Analisis kuantitatif dilakukan cara menganalisis suatu permasalahan yang diwujudkan dengan kuantitatif. Analisis ini menggunakan analisis regresi berganda, uji asumsi klasik, dan uji hipotesis.

\section{Analisis Regresi Berganda}

Berikut adalah persamaan regresi linier berganda :

$$
\mathrm{DA}=\alpha+\beta 1 \mathrm{ACSIZE}+\beta 2 \mathrm{ACMEET}+\beta 3 \mathrm{ACIND}+\beta 4 \mathrm{ACEXP}+\beta 5 \mathrm{KAP}+\mathrm{e}
$$

Keterangan :

DA : Discretionary Accrual

ACSIZE : Ukuran Komite Audit 


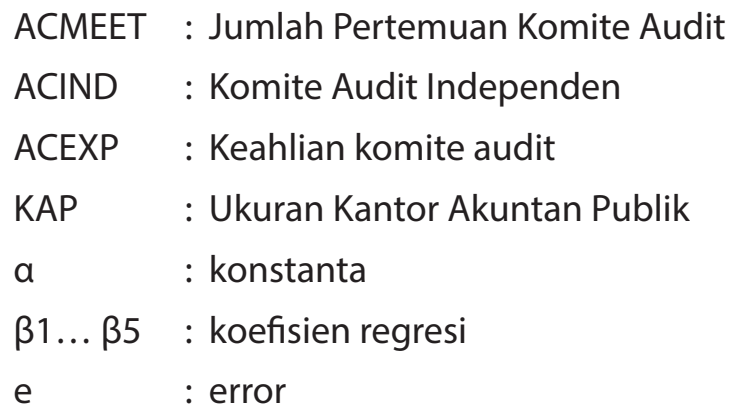

\section{Uji Asumsi Klasik}

\section{Uji Normalitas}

Uji normalitas dilakukan untuk menguji apakah pada suatu model regresi, variabel independen dan variabel dependen ataupun keduanya mempunyai distribusi normal atau tidak normal (Ghozali 2018). Uji normalitas menggunakan uji Kolmogrov-Smirnov (K-S).

\section{Uji Multikolinieritas}

Untuk menguji dan melihat apakah terdapat korelasi antar variabel independen dalam model regresi disebut dengan uji multikolinieritas (Ghozali 2018). Nilai VIF (Variance Inflation Factor) $<10$ atau tolerance $>0,1$ menunjukkan bebas gejala multikolonieritas dalam model regresi.

\section{Uji Autokorelasi}

Uji autokorelasi memiliki tujuan utama yaitu menguji dan melihat apakah dalam model regresi linear terdapat korelasi antara pengganggu pada periode t dengan periode t-1 (Ghozali, 2018).

\section{Uji Heteroskedastisitas}

Uji heteroskedastisitas memiliki tujuan utama yaitu untuk menguji dan melihat apakah di dalam model regresi terjadi ketidaksamaan varian pada residual (error) dari satu observasi ke observasi yang lain (Ghozali 2018). Uji heteroskedastisitas dengan melihat grafik scatterplot.

\section{Uji Hipotesis}

Uji hipotesis dilakukan untuk mendapatkan gambaran mengenai hubungan antara variabel independen dengan variabel dependen. Dalam penelitian ini, pengujian hipotesis dilakukan dengan uji t. Pengambilan keputusan dalam uji t ini didasarkan pada tingkat signifikansi sebesar 5\% atau 0,05 (Ghazali 2018).

\section{HASIL DAN PEMBAHASAN}

\section{Statistik Deskriptif}

Berdasarkan Tabel 1 mengenai statistik deskriptif, variabel (Y) manajemen laba yang diukur dengan diskresioner akrual memiliki nilai minimum 0,9212 dan nilai maksimum 1,2012. Hasil ini menunjukkan bahwa 
Tabel 1. Statistik Deskriptif

\begin{tabular}{lrrrrr} 
& N & Minimum & Maximum & Mean & Std. Deviation \\
\hline Ukuran Komite Audit (X1) & 48 & 2 & 5 & 3,21 & 0,544 \\
\hline Jumlah Pertemuan Komite Audit (X2) & 48 & 3 & 44 & 8,77 & 8,784 \\
\hline Keahlian Komite Audit (X3) & 48 &, 20 & 1,00 & 0,6071 & 0,25194 \\
\hline Ukuran KAP (X4) & 48 & 0 & 1 & 0,50 & 0,505 \\
\hline Manajemen Laba (Y) & 48 & 0,9212 & 1,2012 & 1,022199 & 0,0586821 \\
\hline Valid N (listwise) & 48 & & & & \\
\hline
\end{tabular}

Sumber: Output IBM SPSS Statistics 25

paling rendah nilai diskresioner akrual adalah sebesar 0,9212 yakni AKPI (Argha Karya Prima Industry Tbk). Sedangkan nilai tertinggi diskresioner akrual adalah 1,2012 yang dimiliki oleh BTON (Betonjaya Manunggal Tbk). Sementara nilai rata-rata (mean) manejemen laba dari 48 sampel perusahaan manufaktur sebesar 1,022199 dan standar deviasi sebesar 0,0586821.

Variabel ukuran komite audit (X1) hasil statistik menunjukkan nilai minimum sebesar 2 (dua) artinya terdapat paling sedikit dua anggota komite audit sedangkan maksimum sebesar 5 (lima) artinya di dalam perusahaan manufaktur terdapat 5 (lima) anggota komite audit paling banyak. Nilai rata-rata ukuran komite audit sebesar 3,21 anggota komite audit dengan standar deviasi sebesar 0,544.

Variabel jumlah pertemuan komite audit menunjukkan nilai minimum sebesar 3 (tiga) yang artinya komite audit paling sedikit melaksanakan pertemuan atau pertemuan selama 3 (tiga) kali dalam satu tahun yakni AKPI (Argha Karya Prima Industry Tbk) yang dilakukan pada tahun 2015. Sedangkan nilai maksimum sebesar 44 (empat puluh empat) yang artinya di komite audit paling sering melaksanakan pertemuan atau pertemuan selama 44 (empat puluh empat) kali dalam satu tahun yakni SMGR (Semen Indonesia Tbk) yang dilakukan pada tahun 2016. Nilai rata-rata jumlah pertemuan komite audit yaitu sebesar 8,77 dengan standar deviasi sebesar 8,784.

Variabel komite audit independen menunjukkan nilai minimum sebesar 0,33 yang artinya bahwa komite audit memiliki anggota komite independen sebabnyak 1 (satu) orang. Sedangkan nilai maksimum sebesar 1,00 yang artinya bahwa komite audit memiliki anggota komite independen sebanyak 3 (tiga) orang. Nilai ratarata komite audit independen yaitu sebesar 0,9581 dengan standar deviasi 0,16390. Variabel keahlian komite audit menunjukkan nilai minimum sebesar 0,25 dan maksimum 1,00. Nilai rata-rata sebesar 0,6071 dengan standar deviasi 0,25194.

Variabel ukuran KAP hasil statistik menunjukkan nilai minimum sebesar 0 yang artinya laporan keuangan perusahaan tidak diaudit oleh KAP Big 4, dengan nilai maksimum 1 yang memiliki arti bahwa laporan keuangan perusahaan diaudit oleh KAP Big 4. Nilai rata-rata ukuran KAP yaitu sebesar 0,50 dan ukuran KAP Non Big 4 memiliki persentase 50\% sama dengan KAP Big 4 memiliki persentase 50\%. artinya dari 48 sampel perusahaan terdapat KAP berafiliasi Big 4 sebanyak 24 perusahaan dan KAP berafiliasi Non Big 4 sebanyak 24 perusahaan dengan standar deviasi sebesar 0,505. 


\section{Hasil Uji Asumsi Klasik \\ Hasil Uji Normalitas}

Hasil uji normalitas dengan uji Kolmogrov-Smirnov (K-S) pada penelitian ini menunjukkan nilai test statistic sebesar 0,105 dengan signifikansi 0,200. Sehingga dapat disimpulkan bahwa model regresi telah memenuhi asumsi normalitas karena tingkat signifikansinya di atas 0,05 (sig 0,200 >0,05).

\section{Hasil Uji Multikolinieritas}

Tabel 2. Hasil Uji Multikolinieritas

\begin{tabular}{lcc}
\hline & \multicolumn{2}{c}{ Collinearity Statistics } \\
\cline { 2 - 3 } & \multicolumn{2}{c}{ VIF } \\
\hline Ukuran Komite Audit & 0,462 & 2,165 \\
\hline Jumlah Pertemuan Komite Audit & 0,669 & 1,495 \\
\hline Komite Audit Independen & 0,716 & 1,397 \\
\hline Keahlian Komite Audit & 0,467 & 2,140 \\
\hline Ukuran KAP & 0,650 & 1,539 \\
\hline
\end{tabular}

a. Dependent Variable: Manajemen Laba

Sumber: Output IBM SPSS Statistics 25

Untuk menguji dan melihat apakah terdapat korelasi antar variabel independen dalam model regresi disebut dengan uji multikolinieritas (Ghozali 2018). Nilai VIF (Variance Inflation Factor) $<10$ atau tolerance $>$ 0,1 menunjukkan bebas gejala multikolonieritas dalam model regresi. Berdasarkan Tabel 2, maka dapat disimpulkan bahwa model regresi dalam penelitian ini telah terbebas dari masalah multikolinieritas.

\section{Hasil Uji Autokorelasi}

Uji autokorelasi memiliki tujuan utama yaitu menguji dan melihat apakah dalam model regresi linear terdapat korelasi antara pengganggu pada periode t dengan periode t-1 (Ghozali, 2018). Hasil uji autokorelasi di atas menunjukkan nilai DW 2,.525, nilai ini akan kita bandingkan dengan nilai tabel dengan menggunakan signifikansi 5\%. Untuk penelitian ini menggunakan $n=48$, dapat dilihat di tabel DW pada $n=48$, serta $k=5$ ( $\mathrm{k}$ adalah jumlah variabel independen) diperoleh nilai dl sebesar 1,3167 dan du sebesar 1,7725. Jadi dapat dihitung 4-dl sebesar 2,6833 dan 4-du 2,2275. Karena nilai DW (2,525) berada pada daerah antara ( 4-du 2,2275 $<$ d 2,525 < 4-dl 2,6833), maka dapat disimpulkan bahwa tidak terdapat autokorelasi.

\section{Hasil Uji Heteroskedastisitas}

Pada uji heteroskedastisitas-grafik scatterplot, data sampel tersebar secara acak dan tidak membentuk suatu pola tertentu. Data tersebut bisa terjadi diatas maupun dibawah angka 0 (nol) pada sumbu Y, maka dapat disimpulkan bahwa dalam model regresi ini tidak terjadi masalah heteroskedastisitas. 


\section{Analisis Regresi Berganda}

Tabel 3. Persamaan Regresi Berganda

\begin{tabular}{lccr}
\hline & \multicolumn{2}{c}{ Unstandardized Coefficients } & Standardized Coefficients \\
\cline { 2 - 4 } & $\begin{array}{l}\text { Std. } \\
\text { Error }\end{array}$ & Beta & \\
\hline (Constant) & 1,000 & 0,086 & $-0,161$ \\
\hline Ukuran Komite Audit (X1) & $-0,017$ & 0,023 & 0,119 \\
\hline Jumlah Pertemuan Komite Audit (X2) & 0,001 & 0,001 & 0,369 \\
\hline Komite Audit Independen (X3) & 0,132 & 0,061 & $-0,246$ \\
\hline Keahlian Komite Audit (X4) & $-0,057$ & 0,049 & $-0,356$ \\
\hline Ukuran Kantor Akuntan Publik (X5) & $-0,041$ & 0,021 & \\
\hline
\end{tabular}

Sumber: Output IBM SPSS Statistics 25

Tabel 2 menunjukkan persamaan regresi linear berganda sebagai berikut:

$$
\mathrm{DA}=1 \text { - 0,017 ACSIZE }(X 1)+0,01 \text { ACMEET(X2) + 0,132 ACIND (X3) - 0,057 ACEXP(X4) - 0,041 KAP (X5) }
$$

Dari persamaan diatas diketahui bahwa nilai konstanta yang diperoleh sebesar 1. Hal ini artinya jika variabel independen (ukuran komite audit, jumlah pertemuan komite audit, komite audit independen, keahlian komite audit dan ukuran kantor akuntan publik) tidak ada atau bernilai 1 (satu), maka besarnya manajemen laba yang terjadi adalah sebesar 1 (satu). Koefisien regresi variabel ukuran komite audit bernilai negatif sebesar -0,017. Hal ini menunjukkan bahwa setiap peningkatan satu kesatuan jumlah anggota komite audit akan menurunkan tindakan manajemen laba sebesar -0,017. Variabel jumlah pertemuan komite audit bernilai positif yaitu 0,01 . Hal ini menunjukkan bahwa setiap peningkatan satu kesatuan jumlah pertemuan komite audit dapat menaikkan manajemen laba sebesar 0,01. Variabel komite audit independen bernilai positif yaitu 0,132. Hal ini menunjukkan bahwa setiap peningkatan satu kesatuan anggota komite audit independen dapat menaikkan manajemen laba sebesar 0,132. Variabel keahlian komite audit bernilai negatif sebesar -0,057. Hal ini menunjukkan bahwa setiap peningkatan satu kesatuan anggota yang mempunyai keahlian di komite audit akan dapat menurunkan tindakan manajemen laba sebesar -0,057. Variabel ukuran kantor akuntan publik bernilai negatif sebesar -0,041. Hal ini menunjukkan bahwa setiap peningkatan satu kesatuan kantor akuntan publik bigfour dapat menurunkan tindakan manajemen laba sebesar -0,041.

\section{Hasil Uji Hipotesis (Uji t)}

Berdasarkan hasil tabel 2 dari uji t (uji parsial) menunjukkan untuk variabel ukuran komite audit terhadap manajemen laba menunjukkan nilai signifikansi yang diperoleh sebesar 0,448 tersebut lebih besar dari taraf signifikansi 0,05 artinya ukuran komite audit tidak mempunyai pengaruh dengan arah negatif terhadap manajemen laba (Hipotesis 1 ditolak)

Hasil pengujian untuk variabel jumlah pertemuan komite audit terhadap manajemen laba memberikan Nilai signifikansi sebesar 0,985 lebih besar dari 0,05. Oleh karena itu, pengujian ini menunjukkan bahwa pada taraf signifikansi 5\%, jumlah pertemuan komite audit tidak mempunyai pengaruh dengan arah negatif 
terhadap manajemen laba (Hipotesis 2 ditolak).

Hasil pengujian untuk variabel komite audit independen terhadap manajemen laba memberikan nilai signifikansi yang diperoleh sebesar 0,035 tersebut lebih kecil dari taraf signifikansi 0,05. artinya komite audit independen mempunyai pengaruh dengan arah positif terhadap manajemen laba (Hipotesis 3 diterima).

Hasil pengujian untuk variabel keahlian komite audit terhadap manajemen laba memberikan hasil nilai signifikansi yang diperoleh sebesar 0,246 tersebut lebih besar dari taraf signifikansi 0,05. artinya keahlian komite audit tidak mempunyai pengaruh terhadap manajemen laba ( Hipotesis 4 ditolak).

Hasil pengujian untuk variabel ukuran kantor akuntan publik terhadap manajemen laba memberikan hasil t hitung dengan signifikansi sebesar 0,051 lebih besar dari taraf signifikansi 0,05 artinya ukuran kantor akuntan publik tidak mempunyai terhadap manajemen laba (Hipotesis 5 ditolak).

\section{Hasil Uji Koefisien Determinasi (R2)}

Nilai koefisien determinasi (R2) yang diperoleh dalam penelitian ini adalah sebesar 14,1\%. Artinya bahwa variansi variabel manajemen laba dapat dijelaskan oleh variasi dari kelima variabel ukuran komite audit, jumlah pertemuan komite audit, komite audit independen, keahlian komite audit dan ukuran Kantor Akuntan Publik. Sedangkan sisanya sebesar 85,9\% dijelaskan oleh sebab-sebab lain diluar variable independent dalam model regresi penelitian ini.

\section{PEMBAHASAN}

\section{Pengaruh Ukuran Komite Audit Terhadap Manajamen Laba}

Hasil penelitian ini tidak konsisten dengan penelitian Sihombing dan Laksito (2017), Marsha dan Ghozali (2017), dan Sari (2017), Nugraha (2016) yang mengungkap hasil bahwa komite audit berpengaruh negatif terhadap manejemen laba. Hasil penelitian ini sejalan dengan penelitian yang dilakukan oleh Mughni dan Cahyonowati (2015) dan Ulina et al. (2018) yang menunjukkan bahwa ukuran komite audit tidak berpengaruh terhadap manajemen laba. Hal ini dapat disebabkan karena pembentukan komite audit hanya sebatas memenuhi regulasi atau peraturan yang mensyaratkan bahwa sebuah perusahaan harus mempunyai anggota komite audit. Sehingga keberadaan komite audit belum tentu efektif dalam melaksanakan pengawasan terhadap kinerja manajemen dalam aspek pengendalian perusahaan. Hal ini tentunya membuat komite audit apakah berjumlah sedikit atau banyak anggotanya tidak dapat mengurangi terjadinya tindakan manajemen laba.

\section{Pengaruh Jumlah Pertemuan Komite Audit Terhadap Manajemen Laba}

Hasil penelitian ini bertolak belakang dengan penelitian yang dilakukan oleh Sihombing dan Laksito (2017), Marsha dan Ghozali (2017), dan Sari (2017) yang menyatakan bahwa jumlah pertemuan komite audit berpengaruh negatif terhadap manajemen laba. Namun, penelitian ini sejalan dan konsisten dengan penelitian Mishra (2016) dan Ulina et al. (2018) yang menunjukkan bahwa jumlah pertemuan komite audit tidak berpengaruh terhadap manajemen laba. Hal ini dapat disebabkan pertemuan komite audit hanya bersifat mandatory terhadap peraturan yang menyatakan komite audit untuk melakukan pertemuan atau rapat berkala paling kurang sekali dalam 3 (tiga) bulan. Karena pertemuan yang dilakukan lebih untuk memenuhi 
aturan yang ada komite audit belum tentu dapat melaksanakan tugas dan tanggung jawabnya secara baik. Apabila melakukan rapat, tetapi sangat sedikit membahas terkait internal perusahaan sehingga fungsi dan peran pertemuan komite audit menjadi tidak efektif. Oleh karena itu, berapapun frekuensi pertemuan komite audit dalam setahun artinya tidak ada pengaruh dalam mengurangi manajemen laba yang dilakukan oleh pihak manajemen.

\section{Pengaruh Komite Audit Independen Terhadap Manajemen Laba}

Hasil penelitian ini sejalan dengan penelitian yang dilakukan oleh Amar (2014) yang menunjukkan komite audit independen berpengaruh positif terhadap manajemen laba. Hal ini menunjukkan keberadaan komite audit mempunyai pengaruh terhadap manajemen laba namun tidak sesuai yang diharapkan. Adanya pengawasan dari komite audit yang independen dalam rangka menurunkan manajemen laba. Namun hal ini tidak sesuai dengan hasil yang menunjukkan hubungan positif diantara keduanya. Hal ini perlu menjadi perhatian bagi regulator sehingga dapat merumuskan aturan yang lebih baik agar fungsi komite audit dapat berjalan efektif dan sesuai harapan.

\section{Pengaruh Keahlian Komite Audit Terhadap Manajemen Laba}

Hasil penelitian ini konsisten dengan penelitian yang dilakukan oleh Siagian dan Siregar (2018) yang menyatakan bahwa keahlian komite audit tidak berpengaruh terhadap manajemen laba. Hal ini dapat dikarenakan pembentukan komite audit yang harus memiliki kompetensi di bidang keuangan/akuntansi hanya sebatas memenuhi peraturan yang berlaku saja, yang mana hal tersebut tidak berlaku ditujukan untuk mengurangi terjadinya manajemen laba, walaupun keahlian keuangan/akuntansi komite audit diharap mampu mengurangi manajemen laba.

\section{Pengaruh Ukuran Kantor Akuntan Publik Terhadap Manajemen Laba}

Hasil penelitian ini konsisten dengan penelitian Marsha dan Ghozali (2017), menyatakan bahwa ukuran Kantor Akuntan Publik tidak berpengaruh terhadap manajemen laba. Besar atau kecilnya Kantor Akuntan Publik tidak berpengaruh terhadap manajemen laba. Keberadaan auditor ekternal Bigfour tidak dapat mengurangi manajemen laba dan peran auditor belum mampu mengungkapkan manajemen laba yang dilakukan oleh manajemen, karena perusahaan lebih memiliki keinginan agar kinerja keuangan perusahaan terlihat bagus dimata calon investor dan manajemen laba. Oleh karena itu, ukuran kantor akuntan publik belum dapat dijadikan tolok ukur dalam penurunan manajemen laba di perusahaan.

\section{PENUTUP}

\section{Kesimpulan}

Berdasarkan hasil dan pembahasan penelitian maka kesimpulan penelitian ini adalah komite audit independen berpengaruh terhadap manajemen laba namun belum dapat mengurangi manajemen laba yang dilakukan oleh manajer perusahaan. Sedangkan ukuran komite audit, jumlah pertemuan komite audit, 
keahlian komite audit dan ukuran kantor akuntan publik tidak berpengaruh terhadap manajemen laba. Peran komite audit untuk mengurangi manajemen laba belum optimal. Sehingga perusahaan harus meningkatkan peran komite audit dalam menjalankan tugasnya.

\section{Keterbatasan Penelitian}

Beberapa keterbatasan penelitian untuk penelitian ini adalah penelitian ini hanya menggunakan dari perusahaan manufaktur sektor industri dasar dan kimia, lalu periode yang digunakan pada penelitian ini tergolong cukup pendek yaitu selama 3 tahun (2015-2017). Penggunaan periode penelitian yang pendek dikhawatirkan akan menyebabkan penilaian yang dilakukan menjadi kurang akurat dan kriteria sampel perusahaan penelitian ini hanya memakai mata uang rupiah pada laporan keuangan yang diterbitkan.

\section{Saran untuk Penelitian Mendatang}

Saran untuk penelitian ini adalah dengan menambah data dari seluruh perusahaan manufaktur atau seluruh jenis perusahaan yang terdaftar di Bursa Efek Indonesia. Penggunaan periode penelitian yang cukup pendek dikhawatirkan akan menyebabkan penilaian yang dilakukan menjadi kurang akurat, saran penelitian selanjutnya adalah dengan menambah periode yang lebih panjang dan saran penelitian selanjutnya adalah tidak hanya menggunakan sampel perusahaan go public yang menggunakan mata uang rupiah saja, melainkan mata uang lainnya.

\section{DAFTAR PUSTAKA}

Amar, Anis Ben. "The Effect of Independence Audit Comitte o n Earnings Management: The Case In French". International Journal of Academic Research in Accounting, Finance and Management Sciences, Vol. 4, No.1 (2014): 96-102.

Arrens, Alvin A., Elder, Randal J., and Beasley, Mark S. Auditing dan Jasa Assurance Edisi Kelimabelas Jilid 1. Jakarta: Penerbit Erlangga (2014).

Ayemere, L. Ibadin., dan Afensimi Ellijah. "Audit Committee Attributes and Earnings Management: Evidence from Nigeria". International Journal of Business and Social Research, Vol. 05, Issue 04 (2015).

Challen, Auliffi Ermian., dan Sylvia Veronica Siregar. "Audit Quality on Earning Management and Firm Value". Finance and Banking Journal Vol. 14 No.1 Juni (2012).

Chen, K. Y., Elder, R. J., and Hsieh, Y.-M.. "Corporate Governance and Earnings Management: The Implications of Corporate Governance Best-Practice Principles for Taiwanese Listed Companies". Journal of Contemporary Accounting \& Economics. Vol. 3, No. 2, (2007): 73-105.

Christiani, Ingrid, dan Yeterina Widi Nugrahanti. Pengaruh Kualitas Audit Terhadap Manajemen Laba. Jurnal Akuntansi dan Keuangan, Vol. 16, No. 1. (2014).

Dewi, Eva Rosa dan Khoiruddin "Pengaruh Good Corporate Governance Terhadap Manajemen Laba Pada Perusahaan Yang Masuk Dalam Jii (Jakarta Islamic Index) Tahun 2012-2013". Management Analysis Journal, Vol. 5, No. 3. (2016). 
Florencea, Novia., dan Yulius Kurnia Susanto. "Audit Committee: Woman, Experience, Education on Earnings Management". Advances in Economics, Business and Management Research, Vol 73. (2018).

Ghozali, Imam. Aplikasi Analisis Multivariate Dengan Program IBM SPSS 25. Semarang: Badan Penerbit Universitas Diponegoro, 2018.

Halim, Abdul. Auditing. Yogyakarta: STIM YKPN, 2008.

Idris, Muhammed., et. al. "The Impact Of External Auditor Size On The Relationship Between Audit Committee

Effectiveness And Earnings Management". Investment Management and Financial Innovations, Vol. 15, Issue 3. (2018).

Jensen, C. Michael, and Meckling, H. William. "Theory of The Firm: Managerial Behavior, Agency Cost and Ownership Structure". Journal of Financial Economics, Edition Vol.3, (1976): 305-360.

Juhmani, Omar. "Audit Committee Characteristics and Earnings Management: The Case of Bahrain". International Journal of Accounting and Financial Reporting, Vol. 7, No. 1. (2017).

Kankanamge., Chinta K. "Relationship between Audit Committee Characteristics and Earnings Management in Sri Lanka (2013-2015)". South Asian Institute of Technology and Medicine Ltd. (2016)

Khurnanto R, Farras dan Syaffrudin, Muhammad.. "Pengaruh Komite Audit Dan Audit Eksternal Terhadap Manajemen Laba". Jurusan Akuntansi Fakultas Ekonomika dan Bisnis Universitas Diponegoro, Vol. 4, No. 4, (2015): 1-8.

Kusumaningtyas, Metta., dan Farida, Desy Noor. “Pengaruh Kompetensi Komite Audit, Aktivitas Komite Audit Dan Kepemilikan Institusional Terhadap Manajemen Laba". Jurnal Akuntansi Indonesia , Vol. 4, No. 1, (2015): 66-82.

Lufita, Novi., dan Suryani, Elly. “Pengaruh Kualitas Audit, Komite Audit, Dan Ukuran Perusahaan Terhadap Manajemen Laba (Studi Pada Perusahaan Sektor Manufaktur Yang Terdaftar Di Bursa Efek Indonesia Pada Tahun 2014 - 2016)". e-Proceeding of Management, Vol.5, No.1. (2018).

Marsha, Felicia., dan Ghozali, Imam. “Pengaruh Ukuran Komite Audit, Audit Eksternal, Jumlah Pertemuan Komite Audit, Jumlah Pertemuan Dewan Komisaris Dan Kepemilikan Institusional Terhadap Manajemen Laba (Studi Empiris Perusahaan Manufaktur Yang Terdaftar Di Bei Tahun 2012-2014)". Diponegoro Journal Of Economic, Vol. 6, No. 2, (2017): 1-12.

Mishra, Mamta. "Audit Committee Characteristics and Earnings Management: Evidence from India". International Journal of Accounting and Financial Reporting, Vol. 6, No. 2. (2016).

Mughni, Raisya Hayyu., dan Cahyonowati, Nur. "Pengaruh Karakteristik Komite Audit Dan Kualitas Audit Terhadap Manajemen Laba (Studi Kasus Pada Perusahaan IPO Di Indonesia Tahun 2011-2013)". Diponegoro Journal of Accounting, Vol 4, No. 1, (2015): 1-15.

Nugraha, Nisrina Fatin. “Pengaruh Reputasi Auditor Dan Karakteristik Komite Audit Terhadap Manajemen Laba (Studi Kasus pada Perusahaan Perbankan yang Terdaftar)". Program Studi Akuntansi, Fakultas Ekonomi dan Bisnis Universitas Muhammadiyah Yogyakarta. (2016).

Otoritas Jasa Keuangan. Peraturan Otoritas Jasa Keuangan Nomor 55/POJK.04/2015 Tentang Pembentukan dan Pedoman Pelaksanaan Kerja Komite Audit, (2015): 1-29. 
Prabowo, Muhammad Shidqon. Dasar-Dasar Good Corporate Governance. Yogyalarta: UII Press, 2018.

Prastiti, Anindyah, dan Wahyu Meiranto. "Pengaruh Karakteristik Dewan Komisaris dan Komite Audit Terhadap Manajemen Laba". Diponegoro Jurnal of Accounting, Vol. 2, No. 4, (2013).

Purnomo, Budi S., dan Puji Pratiwi. “Pengaruh Earning Power Terhadap Praktek Manajemen Laba”. Jurnal Media Ekonomi, Vol. 14, No.1, (2009)

Rahmadani, Suci., dan Haryanto. “Manajemen Laba: Peran Keaktifan Komite Audit Dan Auditor Eksternal Big 4 (Studi Empiris Pada Perusahaan Manufaktur Yang Terdaftar Di Bei 2013-2015)". Jurnal Akuntansi Aktual, Vol. 5, No. 1, (2018): 46-62.

Scott, William R. Financial Accounting Theory Fifth Edition. New Jersey: Prentice Hall Inc, 2012.

Siagian, Delfita., dan Sylvia Veronica Siregar. "The Effect of Audit Committee Financial Expertise And Relative Status On Earnings Management Case of Indonesia". Jurnal Akuntansi/Vol. XXII, No. 03, (2018): 321-326.

Sihombing, Margareth A.R., dan Laksito, Herry. "Pengaruh Karakteristik Komite Audit Dan Kualitas Auditor Eksternal Terhadap Manajemen Laba. Diponegoro Journal Of Accounting, Vol. 6, No. 4, (2017): 1-10.

Suri, Natasha., dan Intan Pramesti Dewi. "Pengaruh Mekanisme Good Corporate Governance Terhadap Manajemen Laba (Studi Pada Perusahaan Manufaktur Sektor Food And Beverages Yang Terdaftar Di Bursa Efek Indonesia Periode 2012 - 2016)". Jurnal Sains Manajemen \& Akuntansi, Vol. X, No. 2, (2018).

Sugiyono. Statistika Untuk Penelitian. Bandung: Alfabeta, 2017.

Susanto, Yulius Kurnia. "The Effect Of Audit Committees And Corporate Governance On Earnings Management:

Evidence From Indonesia Manufacturing Industry". International Journal of Business, Economics and Law, Vol. 10, Issue 1. (2016).

Sylvester, Eriabie., dan James, Odia.. "Effects of Characteristics of Audit Committee on Earnings Management in Nigerian Quoted Companies". Sokoto Joumal of Management Studies, Vol. 10, No. 1, (2016).

Ulina, Ryu., Roza Mulyadi., dan Tjahjono, Mazda.“Pengaruh Kualitas Audit Dan Komite AuditTerhadap Manajemen Laba Pada Perusahaan Manufaktur Yang Tercatat Di Bursa Efek Indonesia. Tirtayasa Ekonomika". Jurnal Tirtayasa Ekonomika, Vol. 13, No 1, (2018).

Yateno. Manajemen Laba Pendekatan Model Empiris. Lampung: Laduny Alfatama, 2016.

Zgarni, I., Hlioui, K., \& Zehri, F.. “Effective audit committee, audit quality and earnings management: Evidence from Tunisia". Journal of Accounting in Emerging Economies, Vol. 6, No. 2, (2016): 138-155. 